\title{
Inflammatory response in chronic degenerative endometritis mares treated with platelet-rich plasma
}

\author{
Maria Fernanda S. Reghini ${ }^{a}$, Carlos Ramires Neto ${ }^{a}$, Lorenzo G. Segabinazzi ${ }^{\text {a }}$, \\ Maria Manoela B. Castro Chaves a , Camila de Paula F. Dell'Aqua ${ }^{a}$, \\ Maria Clara C. Bussiere ${ }^{b}$, José Antonio Dell'Aqua Jr ${ }^{a}$, Frederico O. Papa ${ }^{a}$, \\ Marco Antonio Alvarenga ${ }^{a, *}$ \\ ${ }^{a}$ Department of Animal Reproduction and Veterinary Radiology, São Paulo State University - UNESP, Botucatu, Brazi \\ ${ }^{\mathrm{b}}$ Laboratory of Animal Reproduction and Genetic Improvement, North Fluminense State University, Rio de Janeiro, Brazil
}

\section{A R T I C L E I N F O}

\section{Article history:}

Received 18 September 2015

Received in revised form 26 January 2016

Accepted 30 January 2016

\section{Keywords:}

Mare

Chronic degenerative endometritis

Platelet-rich plasma

Endometriosis

Nitric oxide

\begin{abstract}
A B S T R A C T
Degenerative changes of the endometrium are directly related to age and fertility in mares. Chronic degenerative endometritis $(\mathrm{CDE})$ is correlated with uterine fluid retention and reduced ability to clear uterine inflammation. Recent research in the areas of equine surgery and sports medicine has shown that platelet-rich plasma (PRP) treatment acts as an immunomodulator of the inflammatory response. Therefore, the aim of this study was to determine if the uterine infusion of PRP could modulate the local inflammatory response and modify the intrauterine NO concentrations after artificial insemination (AI) in both normal mares and those with CDE. Thirteen mares with endometrium classified as grade III on the histology (mares with $\mathrm{CDE}$ ) and eight mares with endometrial histological classification I or II-a normal mares were selected to investigate the effect of PRP therapy. The mares were inseminated with fresh semen in two consecutive cycles in a crossover study design. Thereby, each mare served as its own control and the treatment was performed with intrauterine PRP infusion four hours after AI. The percentage of neutrophils in uterine cytology (CIT, \%), uterine fluid accumulation observed on ultrasonography (FLU, $\mathrm{mm}$ ) and nitric oxide concentration of uterine fluid $(\mathrm{NO}, \mu \mathrm{M})$ were analyzed before and 24 hours after AI. The results reported that mares with CDE (CIT, $68.3 \pm 3.27$, FLU, $10.7 \pm 1.61)$ have a higher $(\mathrm{P}<0.05)$ intrauterine inflammatory response after AI than normal mares (CIT, $24.4 \pm 3.56$, FLU, 0), but NO concentrations did not differ $(\mathrm{P}>0.05)$ between categories of mares. In treated cycles with PRP, the intrauterine inflammatory response decrease $(\mathrm{P}<0.05)$ in CDE mares (CDE: CIT, $31.4 \pm 6.48$, FLU, $5.5 \pm 1.28$; normal mares: CIT, $13.5 \pm 4.31$, FLU, 0) when compared with nontreated cycle (CDE: CIT, $68.3 \pm 3.27$, FLU, $10.7 \pm 1.61$; NM: CIT, $24.4 \pm 3.56$, FLU, 0), but did not modify NO concentrations in uterine fluid. Thus, we can conclude that PRP was effective in modulating the exacerbated uterine inflammatory response to semen in mares with CDE but did not reduce NO concentrations in intrauterine fluid.
\end{abstract}

(c) 2016 Elsevier Inc. All rights reserved.

\footnotetext{
* Corresponding author. Tel./fax: 0551438116249.

E-mail address: malvarenga@fmvz.unesp.br (M.A. Alvarenga).
}

\section{Introduction}

Chronic degenerative endometritis (CDE) is an alteration of uterine glands and the surrounding stroma, directly related to the age and fertility of mares [1,2]. It is estimated that $30 \%$ of broodmares are older than 18 years, 
[3] and the high value of their progeny encourages the use of these animals in assisted reproduction procedures. The periglandular arrangement of myofibroblasts and extracellular matrix deposition, with glandular alterations in fibrotic foci are important characteristics of CDE [4,5].

Endometrial fibrosis is a progressive condition, which tends to worsen with age [6] and results from repeated episodes of inflammation, such as uterine infection or uterine therapies $[7,8]$. The mucosa of the female reproductive system uses defense mechanism that removes contaminants through a combination of cellular, humoral and mechanical factors of contraction, and lymphatic drainage, which facilitates uterine clearance and elimination of the physiological inflammatory process. Chronic endometritis may develop when uterine defense mechanisms fail [9].

Endometrial biopsy score is the gold standard of uterine health $[10,11]$, and this score is indicative of susceptibility to persistent breeding-induced endometritis (PBIE) $[6,12]$. Mares with severe degenerative endometritis have uterine fluid retention and reduced ability to clear uterine inflammation [6].

Nitric oxide (NO) is generated in many body systems, in both normal physiological and pathological states [13-16]. During inflammation, NO is synthesized by inducible nitric oxide synthase (iNOS) and results from the release of inflammatory signals [17], such as the contact of spermatozoa with the endometrium [18]. Alghamdi et al.[18] reported an increase in endometrial production of iNOS and NO after artificial insemination (AI) in mares susceptible to endometritis, this increase may be associated with myometrial contractility deficiencies in these mares because of the muscle relaxing effect of NO [19].

Treatment of endometritis in mares, aims to correct anatomical defect, reduce the inflammatory response, and reduce contaminations of the uterus [20-22]. Treatments that seem to modulate or even suppress the immune response as a way to reduce postbreeding uterine inflammation have been studied in recent years [23]. There is evidence that the judicious use of steroids or immunomodulators may increase pregnancy rates in mares with uterine fluid accumulation or inflammation [24-27].

Currently, treatment with platelet-rich plasma (PRP) has been used frequently in equine veterinary medicine for various conditions including: in orthopedic surgery, repair of muscles, tendons and ligaments, and reversal of skin ulcers [28-33]. Platelet-rich plasma contains many growth factors important in tissue repair owing to its mitogenic, chemotactic, neovascular, and antiinflammatory effects [34-37]. Treatment with PRP was shown to increase growth factors such as transforming factor $\beta$, insulin-like growth factor-I, fibroblast growth factor, epidermal growth factor, vascular endothelial growth factor in the injured area, and local increase in lipid molecules (lipoxin A4) [38]. In addition, increased levels of chemokines were secreted by macrophages and endothelial cells. The chemokines alter the chemotactic gradient to inhibit the migration of leukocytes from the circulation into the tissue [39]. Another study found that platelets cause an initial suppression of IL-1 released by activated macrophages [40].
The objective of this study was, thus, to determine whether the uterine infusion of PRP could modulate the local inflammatory response and alter intrauterine NO concentrations after $\mathrm{AI}$ in normal mares and in mares with $\mathrm{CDE}$.

\section{Material and methods}

\subsection{Animals}

We used twenty-one crossbred mares, ages 11 to 19 years and weighing between 300 and $400 \mathrm{~kg}$, from the Department of Animal Reproduction and Veterinary Radiology, São Paulo State University, UNESP Botucatu, SP/ Brazil. All animals reported good body condition (score: 6.0-8.0) [41], normal conformation of the external genitalia, remained in similar handling and pastures, and received $2 \mathrm{~kg}$ of concentrated balanced grains, water and mineral salt ad libitum. Mares were divided into two categories: (1) mares with CDE: thirteen mares with endometrium classified as grade III on histology, characterized by a severe degenerative process, according to the classification proposed by Kenney and Doig [42]; and (2) Mares with healthy endometrium (normal mares): eight mares with endometrial histological classification I or II-a [42].

The degree of uterine inflammation before AI was determined by cytology according to the classification proposed by Brook [43], whereby less than 5\% of neutrophils are indicative of a noninflamed endometrium, only these mares were used for the study.

\subsection{Preparation of PRP}

Platelet-rich plasma was prepared by the method described by Carmona et al.[29]; in brief, 100-mL blood samples were collected from each animal by puncture of the external jugular vein and conditioned into tubes containing 3.2\% sodium citrate anticoagulant.

Blood samples were homogenized and immediately centrifuged at $120 \times g$ for 10 minutes. From each centrifuged tube, the upper $50 \%$ of the plasma was discarded. To use plasma containing a more concentrated amount of platelets, a second centrifugation was performed. For this purpose, the plasma obtained after the first centrifugation was aspirated with a sterile syringe and transferred into two plastic tubes without anticoagulant, and further centrifuged at $240 \times g$ for 10 minutes. Subsequently, the supernatant was discarded, and the remaining fraction was used as PRP. The tubes with PRP were placed in an isothermal box (Botuflex, Botupharma, Botucatu/SP, Brazil) to maintain a controlled temperature between $20{ }^{\circ} \mathrm{C}$ and $25{ }^{\circ} \mathrm{C}$, for 1 hour until application.

Platelets were activated to release platelet granules immediately before infusion with calcium chloride solution (Wiener Laboratory, SP, Brazil) at $0.068 \mathrm{mEq}$ calcium for each $\mathrm{mL}$ of PRP [44]. The minimal platelet concentration used as a treatment was 250.000 platelets $/ \mu \mathrm{L}$.

\subsection{Semen collection and preparation of insemination doses}

Spermatozoa from a single stallion were used after ejaculate collection using an artificial vagina (Botupharma, 
Botucatu/SP, Brazil). Gel fraction was removed using a nylon filter and the semen was diluted with a skimmed milk based extender (Botu-semen, Botupharma, Botucatu, SP, Brazil) in a ratio 1:1 (the same product was used for all semen samples). After dilution, sperm motility was measured by computerized analysis (Hamilton Thorne Research, Danvers, USA) and the sperm concentration was measured using a Neubauer chamber. Next samples containing sperm concentrations of $800 \times 10^{6}$ were prepared.

\subsection{Assignment of groups and treatment administration}

Mares were examined by transrectal palpation and ultrasonography once daily to determine when they were in estrus. When a 35-mm follicle or more was detected and endometrial edema at least grade 2 was diagnosed (min. grade 0; max. grade 4) [45], ovulation induction was performed with an intramuscular injection of $1 \mathrm{mg}$ of deslorelin acetate (Sincrorelin, Ouro Fino, Brazil). Inseminations with fresh semen $\left(800 \times 10^{6}\right.$ total spermatozoa) were performed 24 hours after induction of ovulation.

Mares in both groups were randomly assigned by lottery to control and treated cycle in a crossover study. In the control cycle, the animals had no intrauterine infusion or pharmacological interference. In the treated cycle, $20 \mathrm{~mL}$ of PRP was infused 4 hours after AI with an insemination pipette inserted into the uterine body. Mares received only one treatment per estrous cycle. Owing to multiple uterine samples being collected during the estrous cycle, each mare served as their own control to reduce a sampling effect on data analysis. Ultrasonographic examinations, uterine exfoliative cytology and collection of uterine secretion were performed 24 hours before (Pre-AI) and 24 hours after (Post-AI) AI, regardless of treatment.

All intrauterine procedures were performed using sterilized material with the examiner wearing a long sterile obstetric glove to minimize the potential for contamination of the uterus with pathogens. Before all intrauterine procedures, each mare's perineal region was cleaned with a mild detergent, rinsed with clean water three times, and dried with paper towels.

\subsection{Sampling strategy}

Transrectal ultrasound evaluations were performed 24 hours before and 24 hours after AI, before sample collection or treatment. The presence or absence of fluid was recorded, and if present, the intrauterine fluid column was measured in millimeters in the region of the bifurcation of the uterine horns.

Endometrial exfoliative cytology was performed 24 hours before and 24 hours after AI. Endometrial samples were obtained using a cytobrush (Kolplast ci Ltda, Brazil) with a contamination protection apparatus (Botupharma, Brazil) as described by [46]. After collection, the slides were air-dried and stained by Dip Quick (Instant Prov; NewProv). The samples were then microscopically examined under oil immersion $(1000 \times)$, and the percentage of polymorphonuclear neutrophils (PMNs) per 100 epithelial cells was randomly determined.
Collection of uterine secretion was performed through a sterile tampon inserted into the uterus (feminine absorbent mini model, OB, Johnson \& Johnson) using an stainless steel applicator, inserted into the uterus as previously described [18]. The tampon was removed after 30 minutes and immediately placed in a sterile syringe. The syringe plunger was pressed to release the liquid from the tampon. The liquid recovered from the uterus was centrifuged $(3000 \times \mathrm{g}$ for 10 minutes) as previously described [47] to remove the cells, and the supernatant was frozen at $-20^{\circ} \mathrm{C}$ until the NO evaluations were performed.

\subsection{Nitric oxide evaluation}

Freezing does not alter the concentration of NO [18], and thawed uterine secretion samples were used for these measurements. To reduce nitrate to nitrite an aliquot of $40 \mu \mathrm{L}$ of the stored sample was incubated in a mixture containing $1000-\mu \mathrm{L}$ nitrate reductase, $1000 \mu \mathrm{L}$ of $\mathrm{NADPH}$ cofactor $(5 \mathrm{mg} / \mathrm{mL})$ diluted in deionized water and $1000 \mu \mathrm{L}$ of PBS $(0.5 \mathrm{M})$. The samples were incubated in a 96-well plate at $37{ }^{\circ} \mathrm{C}$ for $14-16$ hours. After nitrate reduction, total nitrite was determined by the addition of Griess reagent to the samples and the color absorbance was spectrophotometrically read at $540 \mathrm{~nm}$ (Multiskan EX primary EIA, v 2.1-0) [48]. The standard curve for nitrite was diluted in PBS containing concentrations ranging from 0.5 to $400 \mu \mathrm{M}$. The intraassay coefficient of variation was $9.2 \%$. The absorbance values obtained in samples with preestablished concentrations were used to construct the dispersion curve. The total NO amount was determined on the basis of the total volume of the uterine secretions in the tampon at the time of sampling [18].

\subsection{Statistical analysis}

Data on PMNs, uterine fluid and NO concentrations were evaluated using the Kolmogorov-Smirnov normality test, to test its Gaussian distribution. Parametric continuous data were compared by ANOVA followed by Tukey test and nonparametric data were tested using Kruskal-Wallis test followed by the Dunns test. $P$ values less than 0.05 were considered statistically significant.

\section{Results}

\subsection{Normal mares $\times$ mares with $C D E$}

In both categories of mares, the percentage of PMNs in uterine exfoliative cytology significantly increased 24 hours after AI $(\mathrm{P}<0.05)$ (Fig. 1); however, a market increase $(\mathrm{P}<0.05)$ in the number of PMNs was observed in mares with CDE as compared with normal mares (Fig. 1).

Intrauterine fluid was not detected in any mare before AI, whereas 24 hours after AI, intrauterine fluid accumulation significantly increased $(P<0.05)$. The intrauterine fluid was detected in 12 (92\%) mares with CDE, but not in normal mares before or after AI.

NO concentration in the intrauterine fluid did not significantly differ $(\mathrm{P}>0.05)$ in normal or CDE mares and before or after AI (Fig. 2). 


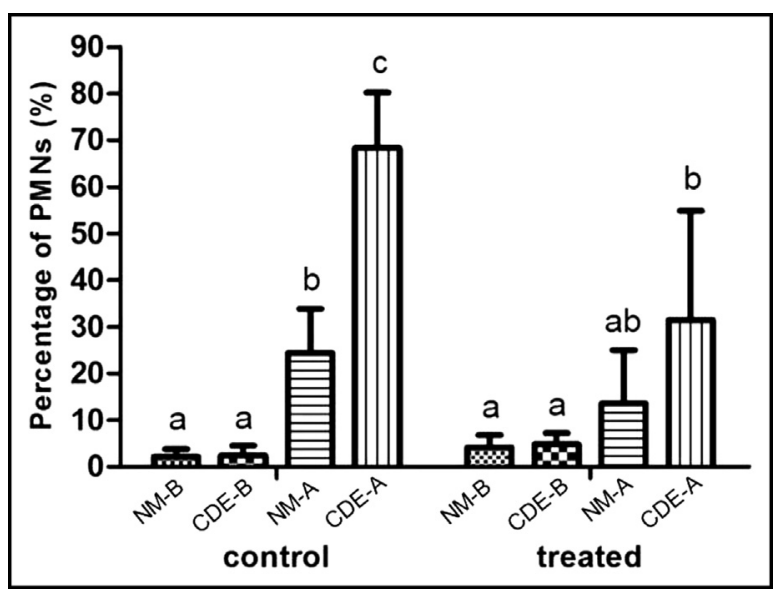

Fig. 1. Percentage of polymorphonuclear cells (PMNs) in uterine exfoliative cytology 24 hours before $\mathrm{AI}$ in mares with healthy endometrium (NM-B); 24 hours before $\mathrm{AI}$ in mares with $\mathrm{CDE}(\mathrm{CDE})$ (CDE-B); 24 hours after $\mathrm{AI}$ in mares with healthy endometrium (NM-A); 24 hours after AI in mares with CDE (CDE-A) in nontreated (control) and treated cycles with PRP (treated). Columns with different superscript $\left({ }^{\mathrm{a}, \mathrm{b}, \mathrm{c}}\right)$ are significantly different $(\mathrm{P}<0.05)$. PRP, platelet-rich plasma.

\subsection{Effect of PRP treatment}

A significant increase $(\mathrm{P}<0.05)$ in the percentage of PMNs 24 hours after AI was observed in both treated and untreated cycles in mares with CDE and only in the untreated cycle of normal mares. No significant change $(P>0.05)$ in PMNs was detected in normal PRP-treated mares (Fig. 1).

Moreover, a significant reduction $(\mathrm{P}<0.05)$ in the percentage of PMNs after AI was observed in mares with CDE that were treated with PRP. This percentage was similar $(\mathrm{P}>0.05)$ to that in normal mares in treated and untreated cycles after AI. Normal mares did not show $(P>0.05)$ a significant reduction in PMNs in the treated cycle compared with untreated cycle (Fig. 1).

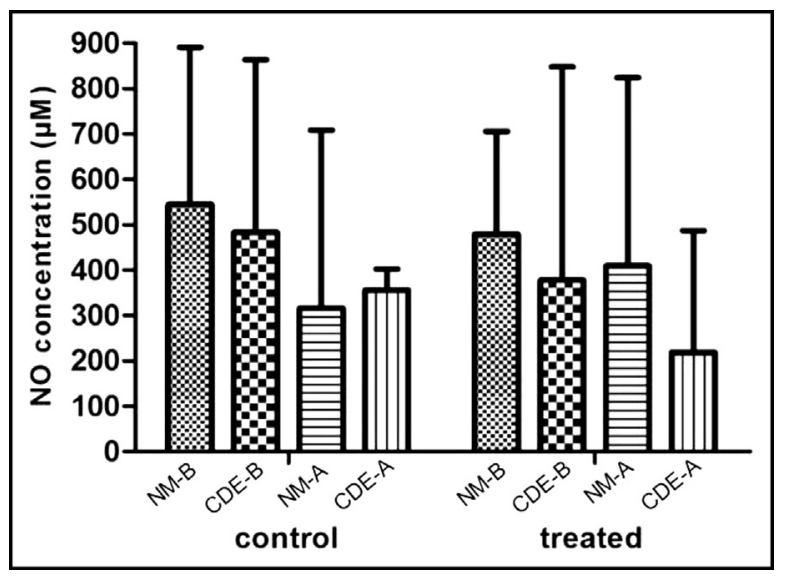

Fig. 2. NO concentrations in intrauterine fluid 24 hours before $A I$ in mares with healthy endometrium (NM-B); 24 hours before $\mathrm{AI}$ in mares with CDE (CDE) (CDE-B); 24 hours after $\mathrm{AI}$ in mares with healthy endometrium (NM-A); 24 hours after $\mathrm{AI}$ in mares with $\mathrm{CDE}$ (CDE-A) in nontreated (control) and treated cycles with PRP (treated). PRP, platelet-rich plasma.
A significant reduction in the intrauterine fluid after AI was observed $(\mathrm{P}<0.05)$ in the PRP-treated cycle in mares with CDE, compared with the untreated cycle (Fig. 3). In normal mares, the intrauterine fluid was not detected at either stage $(\mathrm{P}>0.05)$.

NO concentration in intrauterine fluid was not different $(P>0.05)$ at any time and was not modified $(P>0.05)$ by treatment with PRP (Fig. 2).

\section{Discussion}

The present study found that mares with CDE reported a high intrauterine inflammatory response post-AI. These mares reported increased PMN levels on endometrial cytology and intrauterine fluid retention 24 hours after AI when compared with mares with healthy endometrium. These findings are consistent with those of previous studies $[2,6,12,49,50]$ that observed an association between an advanced degree of endometrial degeneration with uterine inflammation and fluid retention after insemination.

The inflammation may occur because of the impaired uterine clearance in mares with CDE. Damage to uterine glands and blood vessels may lead to decrease lymphatic drainage and circulation in uterus [2,51]. Stolla and Bollwein $\mathrm{H}$ [52] and Esteller-Vico et al.[53] reported a decrease in uterine blood perfusion in mares with higher degrees of endometrial degeneration. Owing to the elevated blood perfusion, increased intrauterine fluid accumulation occurs, which is associated with migration of neutrophils through blood vessel walls into the uterine lumen during the inflammatory process [54].

In both categories of mares, PRP treatment was able to reduce the number of neutrophils present in the uterine lumen at 24 hours after breeding. This can be explained by the antiinflammatory effects of PRP described by Metcalf [55], who observed a downregulation in the expression of intrauterine proinflammatory cytokines (IL-1 $\beta$, IL-6, and IL8) after insemination in PBIE susceptible mares treated with PRP. In another study, Metcalf [56] observed an expressive increase in fertility rates of barren mares.

A reduction in after breeding fluid accumulations was also observed in PRP-treated mares with CDE, indicating a

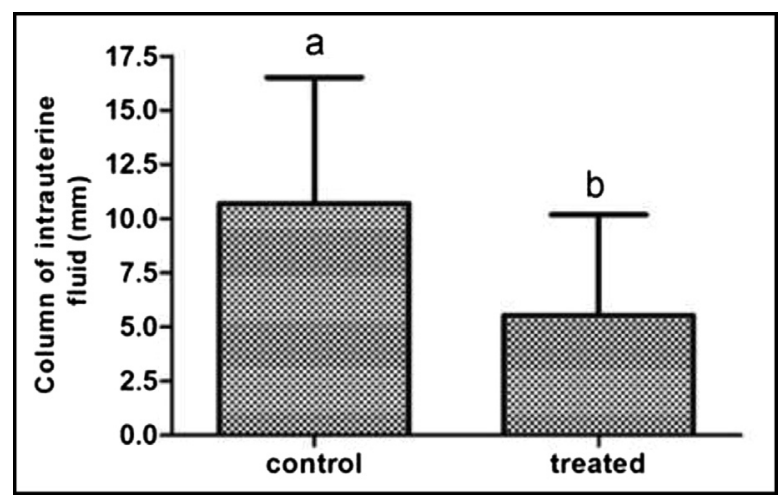

Fig. 3. Column of intrauterine fluid 24 hours after AI in mares with chronic degenerative endometritis between nontreated (control) and treated cycle with PRP (treated). Columns with different superscript $\left({ }^{\mathrm{a}, \mathrm{b}}\right)$ are significantly different $(\mathrm{P}<0.05)$. PRP, platelet-rich plasma. 
downregulation of the inflammatory process. A similar result was observed by Metcalf [56] using PRP before AI. Other immunomodulatory therapies, such as glucocorticoids (predinisolone and dexametasone) [25,26], mesenchymal stem cells [57], autologous conditioned serum [57] and mycobacterium cell wall extract [58], have been shown to reduce fluid accumulation and intrauterine neutrophils number after AI in mares susceptible to PBIE. Differences in intrauterine, NO concentrations were not observed in this study between before and after AI time points, or between categories of mares. Woodward et al.[59] and Fioratti et al.[47] also did not observe differences between intrauterine NO concentrations before and 24 hours after AI, as between categories of mares (resistant and susceptible to PBIE) in these time points. Woodward et al.[59] also observed similar results of iNOS enzymes production by equine endometrium before and 24 hours after $\mathrm{AI}$ and between resistant and susceptible mares.

These results suggest that NO production is not only related to the increase of PMNs. There is evidence that the vasodilator effect of estrogen is attributed to its direct action on vascular smooth muscle cells or due to endothelial activation [60], with subsequent release of NO [61]. Several researchers have shown that, because of the production of iNOS and endothelial nitric oxide synthase by the equine endometrium, NO found in the uterine lumen of these animals is not only produced by inflammatory cells but could also be secreted by endothelial cells, endometrial glands, fibroblasts, and the myometrium [62,63]. According to Alghamdi et al.[18], neutrophils present in the endometrium do not report the capacity to produce NO because they do not display any isoform of NOS.

Intrauterine NO concentrations did not differ between treated and nontreated groups in both categories of mares. The present findings are in agreement with previous ones $[47,59]$, wherein no differences in intrauterine NO concentrations were noted at 6 and 24 hours after AI respectively, in susceptible mares after dexamethasone treatment. In the same study, Woodward et al.[59] observed a reduction in the concentration of total intrauterine NO in susceptible mares treated with mycobacterium cell wall extract, which is considered an immunomodulator. However, using this same treatment, Christoffersen et al.[58] and Rogan et al.[64] did not observe a reduction in neutrophils numbers in mares with induced infectious endometritis. These findings also suggest that PNMs are not the major factor responsible for the production of NO into the uterus.

Metcalf et al.[55] using PRP treatment in susceptible mares, observed a decrease 1 day after $\mathrm{AI}$ on the expression of iNOS in the endometrium. According to Woodall et al.[40], PRP caused an initial in vitro suppression of proinflammatory cytokine IL-1 release from activated macrophage, which is an inducer of iNOS [65]. Similarly Woodward et al.,[66] reported that dexamethasone modulates the expression of the proinflammatory cytokine IL1$\beta$ after breeding in susceptible mares but did not show an effect on intrauterine iNOS or NO production [6].

Woodward et al.[59] did not detect differences on the expression of iNOS between treated or nontreated mares with mycobacterium cell wall extract but observed decrease in total intrauterine NO in the same time point, showing that these two markers do not have the same correlation, because iNOS is responsible for the synthesis of NO during inflammation but is not the only factor. Other NOS are responsible for production of NO by equine uterine tissue and in many body systems [13-16,62,67,68] and its regulation by steroids and cytokines $[63,69,70]$.

In this study, we used intrauterine PRP treatment to modulate the inflammatory reaction in mares with CDE. Chronic degenerative endometritis is directly related to increasing age and these animals represent a significant percentage of breeding mares in assisted reproduction programs. This protocol can thus be used as a complementary treatment for this category of mares.

In conclusion, treatment with PRP modulated the inflammatory response after breeding in mares with CDE, thereby reducing the influx of PMNs into the uterine lumen and prevention intrauterine fluid retention. However, PRP treatment did not affect intrauterine NO levels. Additional studies are ongoing to determine the effects of PRP on fertility rates in these mares.

\section{References}

[1] Ricketts SW, Alonso S. The effect of age and parity on the development of equine chronic endometrial disease. Equine Vet J 1991; 23:189-92.

[2] Hoffmann C, Ellenberger C, Mattos RC, Aupperle H, Dhein S, Stief B, et al. The equine endometrosis: new insights into the pathogenesis. Anim Reprod Sci 2009;111:261-78.

[3] Alvarenga MA, Carmo MT. Biotecnologias em reprodução equina: o que há de novo para o veterinário de campo? Braz J Equine Med 2009;26:4-8.

[4] Walter I, Handler J, Reifinger M, Aurich C. Association of endometrosis in horses with differentiation of periglandular myofibroblasts and changes of extracellular matrix proteins. Reproduction 2001; 121:581-6.

[5] Hoffmann C, Bazer FW, Klug E, Allen WR, Aupperle H, Ellenberger C, et al. Morphofunctional studies regarding the pathogenesis of the equine endometrosis with special emphasis on uterine secretions-preliminary results. Pferdeheilkunde 2003;19:666-9.

[6] Woodward EM, Christoffersen M, Campos J, Squires EL, Troedsson MHT. Susceptibility to persistent breeding-induced endometritis in the mare: relationship to endometrial biopsy score and age, and variations between seasons. Theriogenology 2012;78:495-501.

[7] Van Camp SD. Uterine abnormalities. In: McKinnon AO, Voss JL, editors. Equine reproduction. Philadelphia: Lea \& Febiger; 1993. p. 392-6.

[8] Troedsson MHT. Diseases of the uterus. In: Robinson ND, editor. Current therapy in equine medicine. Philadelphia: W.B. Saunders; 1997. p. $517-23$

[9] Leblanc MM. Persistent mating-induced endometritis. In: Robinson NE, editor. Current therapy in equine medicine. Fifth edition. St. Louis: Elsevier Science; 2003. p. 234-7.

[10] Schlafer DH. Equine endometrial biopsy: enhancement of clinical value by more extensive histopathology and application of new diagnostic techniques? Theriogenology 2007;68:413-22.

[11] Ludwig S, Schoon D, Aupperle H, Von Reiswitz A, Schoon HA. Angiopathies in the equine endometrial biopsy-a marker for extrauterine vascular lesions? Pferdeheilkunde 2001;17:608-14.

[12] Troedsson MH, Moraes MJ, Liu IK. Correlations between histologic endometrial lesions in mares and clinical response to intrauterine exposure with Streptococcus zooepidemicus. Am J Vet Res 1993;54: 570-2.

[13] Angulo J, Wright HM, Cuevas P, Gonzalez- Corrochano R, Fernandez A, Cuevas B, et al. Nebivolol dilates human penile arteries and reverses erectile dysfunction in diabetic rats through enhancement of nitric oxide signaling. J Sex Med 2010;7:2681-97.

[14] Eleftheriadis T, Liakopoulos V, Antoniadi G, Stefanidis I, Galaktidou G. Arginase type I as a marker of coronary heart disease in hemodialysis patients. Int Urol Nephrol 2010;43:1187-94. 
[15] Gupta SP, Patel S, Yadav S, Singh AK, Singh S, Singh MP. Involvement of nitric oxide in maneb- and paraquat-induced Parkinson's disease phenotype in mouse: is there any link with lipid peroxidation? Neurochem Res 2010;35:1206-13.

[16] Zanetti M, Cappellari GG, Burekovic I, Barazzoni R, Stebel M, Guarnieri G. Caloric restriction improves endothelial dysfunction during vascular aging: effects on nitric oxide synthase isoforms and oxidative stress in rat aorta. Exp Gerontol 2010;45:848-55.

[17] Griscavage JM, Wilk S, Ignarro LJ. Inhibitors of the proteasome pathway interfere with induction of nitric oxide synthase in macrophages by blocking activation of transcription factor NF-kB. Proc Natl Acad Sci U S A 1996;93:3308-12.

[18] Alghamdi AS, Foster DN, Carlson CS, Troedsson MH. Nitric oxide levels and nitric oxide synthase expression in uterine samples from mares susceptible and resistant to persistent breedinginduced endometritis. Am J Reprod Immunol 2005;53:230-7.

[19] Liu I, Rakestraw PA, Coit C, Harmon F, Snyder J. An in vitro investigation of the mechanism of neuromuscular regulation in myometrial contractility. Pferdeheilkunde 1997;13:557.

[20] Asbury AC. Endometritis in the mare. In: MORROW DA, editor Current therapy in theriogenology. Second edition. Philapelphia: W. B. Saunders; 1986. p. 718-22.

[21] Langoni H, Alvarenga MA, Papa FO, Sakamoto C, Simon JJ, Listoni JFP, et al. Estudo microbiológico e citológico do trato genital de éguas. Arq Bras Med Vet Zootec 1994;46:623-36.

[22] Losinno L, Alvarenga MA. Fatores que afetam a taxa de recuperação embrionária em eqüinos. Acta Sci Vet 2006;34:22-32.

[23] Leblanc MM, Causey RC. Clinical and subclinical endometritis in the mare: both threats to fertility. Reprod Domest Anim 2009;44: $10-22$.

[24] Fumuso EA, Giguère S, Wade J, Rogan D, Videladorna I, Bowden RA. Endometrial IL-1 $\beta$, IL- 6 and TNF- $\alpha$, mRNA expression in mares resistant or susceptible to post-breeding endometritis and immunomodulation. Vet Immunol Immunopathol 2003;96:31-41.

[25] Dell' Aqua JA, Papa FO, Lopes MD, Alvarenga MA, Macedo LP, Melo CM. Modulation of acute uterine inflammatory response after artificial insemination with equine frozen semen. Anim Reprod Sci 2006;94:270-3.

[26] Bucca S, Carli A, Buckley T, Dolci G, Fogarty U. The use of dexamethasone administered to mares at breeding time in the modulation of persistent mating induced endometritis. Theriogenology 2008; 70:1093-100.

[27] Papa FO, Dell'aqua Jr JA, Alvarenga MA, Melo CM, Soares ZF, Lopes MD. Use of corticosteroid therapy on the modulation of uterine inflammatory response in mares after artificial insemination with frozen semen. Pferdeheilkunde 2008;24:79-82.

[28] Prades M, Abellanet I, Carmona JU, Argüelles D, Masri M. Platelet rich plasma: a realistic alternative in tissue repair. In: Proceedings of the 15th Annual Meeting European College of veterinary Surgeons, Seville. Seville: ECVS; 2006. p. 211-6.

[29] Carmona JU, Arguelles D, Climent F, Prades M. Autologous platelet concentrates as a treatment of horses with osteoarthritis: a preliminary pilot clinical study. J Equine Vet Sci 2007;17:167-70.

[30] Arguelles D, Carmona JU, Climent F, Muñoz E, Prades M. Autologous platelet concentrates as a treatment for musculoskeletal lesions in five horses. Vet Rec 2008;162:208-11.

[31] Maia L, Souza MV, Ribeiro Júnior JI, Oliveira AC, Alves GES, Benjamin LA. Platelet-rich plasma in the treatment of induced tendinopathy in horses: histologic evaluation. J Equine Vet Sci 2009;29:618-26.

[32] Ridermann G, Cislakova M, Arndt G, Carstanjen B. Autologus conditioned plasma therapy of tendon and ligament lesions in seven horses. J Vet Sci 2010;11:173-5.

[33] López C, Carmona JU, Samudio I. Use of autologous concentrateplasm for the treatment of a scapular fracture and brachial plexus injury caused by shot in a horse. Arch Med Vet 2010;42:209-14.

[34] Gonshor A. Technique for producing platelet-rich plasma and platelet concentrate: background and process. Int J Periodontics Restorative Dent 2002;22:547-57.

[35] Kevy SV, Jacobson MS. Comparision of methods for point of care preparation of autologous platelet gel. J Extra Corpor Technol 2004; 36:28-35.

[36] Mazzocca AD, McCarthy MBR, Intravia J, Beitzel K, Apostolakos J, Cote MP, et al. An in vitro evaluation of the anti-inflammatory effects of platelet-rich plasma, ketorolac, and methylprednisolone. J Arthroscopic Relat Surg 2013;29:675-83.

[37] Kim HJ, Yeom JS, Koh YG, Yeo JE, Kang KT, Kang YM, et al. Antiinflammatory effect of platelet-rich plasma on nucleus pulposus cells with response of TNF- $\alpha$ and IL-1. J Orthop Res 2014;32: $551-6$.
[38] El-Sharkawy H, Kantarci A, Deady J, Hasturk H, Liu H, Alshahat M, et al. Platelet-rich plasma: growth factors and anti-inflammatory properties. J Periodontol 2007;78:661-9.

[39] Alam R, Forsythe PA, Lett-Brown MA, Grant JA. Interleukin-8 and RANTES inhibit basophil histamine release induced with monocyte chemotatic and activating factor/monocyte chemoattractant peptide- 1 and histamine releasing factor. Am J Respir Cell Mol Biol 1992;7:427-33.

[40] Woodall Jr J, Tucci M, Mishra A, Asfour A, Benghuzzi H. Cellular effects of platelet rich plasma interleukin1 release from PRP treated macrophages. Biomed Sci Instrum 2008;44:489-94.

[41] Henneke DR, Potter GD, Kreider JL, Yeates BF. Relationship between condition score, physical measurement, and body fat percentage in mares. Equine Vet J 1983;15:371-2.

[42] Kenney RM, Doig PA. Equine endometrial biopsy. In: Marrow D, editor. Current therapy in theriogenology: Diagnosis, treatment, and prevention of reproductive Diseases in Small and Large animals. Second Edition. Philadelphia: W.B. Saunders; 1986. p. 723-9.

[43] Brook D. Uterine cytology. In: McKINNON AO, VOSS JL, editors. Equine reproduction. Philadeplhia: Lea \& Febiger; 1993. p. 246-53.

[44] Arguelles D, Carmona J, Pastor JD, Iborra A, Viñals L, Martinez P, et al. Evaluation of single and double centrifugation tube method for concentrating equine platelets. Res Vet Sci 2006;81:237-45.

[45] Samper JC. Induction of estrous and ovulation: why some mares respond and others do not. Theriogenology 2008;70:445-7.

[46] Alvarenga MA, Iwana De Matos MC. Utilização da escova ginecológica cytobrush na coleta de material endometrial de éguas. Arquivo Brasileiro de Medicina Veterinária e Zootecnia 1990;42:67-8.

[47] Fioratti EG, Villaverde AISB, Avanzi BR, Leal ACMS, CaldasBussiere MC, Alvarenga MA. Nitric oxide concentration in free uterine fluid after dexamethasone treatment of mares resistant and susceptible to endometritis (Abstract). Anim Reprod Sci 2010;121S:113-4.

[48] Green LC, Wagner DA, Glogowski J, Skipper PL, Wishnok JS Tannenbaum SR. Analysis of nitrate, nitrite, and [15N] nitrate in biological fluids. Anal Biochem 1982;126:131-8.

[49] Flores JM, Rodriguez A, Sanchez J, Gomez-Cuetara C, Ramiro F. Endometrosis in mares: incidence of histopathological alterations. Reprod Domest Anim 1995;30:61-5.

[50] Ferreira-Dias GM, Nequin LG, King SS. Morphologic comparisons among equine endometrium categories I, II and III, using light and transmission electron microscopy. Am J Vet Res 1999; 60:49-55.

[51] Grüninger B, Schoon HA, Schoon D, Menger S, Klug E. Incidence and morphology of endometrial angiopathies in mares in relationship to age and parity. J Comp Pathol 1998;119:293-309.

[52] Stolla R, Bollwein H. Color Doppler sonography of the uterine artery in subfertile mares. Pferdeheilkunde 1997;13:547.

[53] Esteller-Vico A, Liu I, Brosnan RJ, Steffey EP. Uterine vascular elastosis and its effect on uterine blood flow in cyclic mares. Anim Reprod Sci Suppl 2010;121:87-8.

[54] Burleson MD, LeBlanc MM, Riddle WT, Hendricks KEM. Endometrial microbial isolates are associated with different ultrasonographic and endometrial cytology findings in Thoroughbred mares. Anim Reprod Sci Suppl 2010;121:103.

[55] Metcalf ES, Scoggin K, Troedsson MHT. The effect of platelet-rich plasma on endometrial pro-inflamatory cytokines in susceptible mares following semen deposition (Abstract). J Equine Vet Sci 2012; 32:498.

[56] Metcalf ES. The effect of platelet-rich plasma (PRP) on intraluminal fluid and pregnancy rates in mares susceptible to persistent mating-induced endometritis (PMIE) (Abstract). J Equine Vet Sci 2014;34:128.

[57] Ferris RA, Frisbie DD, Mccue PM. Use of mesenchymal stem cells or autologous conditioned serum to modulate the inflammatory response to spermatozoa in mares. Theriogenology 2014;82:36-42.

[58] Christoffersen M, Woodward EM, Bojesen AM, Petersen MR, Squires EL, Lehn-Jensen $\mathrm{H}$, et al. Effect of immunomodulatory therapy on the endometrial inflammatory response to induced infectious endometritis in susceptible mares. Theriogenology 2012; 78:991-1004.

[59] Woodward EM, Christoffersen M, Campos J, Horohov DW, Scoggin KE, Squires E, et al. An investigation of uterine nitric oxide production in mares susceptible and resistant to persistent breeding-induced endometritis and the effects of immunomodulation. Reprod Domest Anim 2013;48:554-61.

[60] Scott PA, Tremblay A, Brochu M, St-Louis J. Vasorelaxant action of $17 \beta$-estradiol in rat uterine arteries: role of nitric oxide synthases and estrogen receptors. Am J Physiol Heart Circ Physiol 2007;293: 3713-9. 
[61] Caulin-Glaser T, Garcia-Cardena G, Sarrel P, Sessa WC, Bender JR. 17Beta estradiol regulation of human endothelial cell basal nitric oxide release, independent of cytosolic Ca2 + mobilization. Circ Res 1997; 81:885-92.

[62] Welter H, Bollweinu H, Weber F, Rohr S, Einspanier R. Expression of endothelial and inducible nitric oxide synthases is modulated in the endometrium on cyclic and early pregnant mares. Reprod Fertil Dev 2004;16:689-98.

[63] Roberto Da Costa RP, Ferreira-Dias G, Mateus L, Korzekwa A Andronowska A, Platek R, et al. Endometrial nitric oxide production and nitric oxide synthases in the equine endometrium: relationship with microvascular density during the estrous cycle. Domest Anim Endocrinol 2007;32:287-302.

64] Rogan D, Fumuso E, Rodriguez E, Wade J, Sanchez Bruni SF. Use of a mycobacterial cell wall extract (MCWE) in susceptible mares to clear experimentally induced endometritis with streptococcus zooepidemicus. J Equine Vet Sci 2007;27:112-7.

[65] Persichini T, Cantoni O, Suzuki H, Colasanti M. Cross-talk between constitutive and inducible NO synthase: an update. Antioxid Redox Signal 2006;8:949-54.
[66] Woodward E., Christofferesn M., Campos J., Bentancourt A., Horohov D., Scoggin K.E., et al. Endometrial cytokine expression in mares with different resistance to persistent breeding induced endometritis (PBIE) at multiple time points after insemination. In: 44th Annual Meeting for the Society for the Study of Reproduction. Portland, OR; 2011. 85: 77.

[67] Tripathi P. Nitric oxide and immune response. Indian J Biochem Biophys 2007;44:310-9.

[68] Gebhardt S, Merkl M, Herbach N, Wanke R, Handler J, Bauersachs S. Exploration of global gene expression changes during the estrous cycle in equine endometrium. Biol Reprod 2012;87:136.

[69] Honnens A, Weisser S, Welter H, Einspanier R, Bollwein H. Relationships between uterine blood flow, peripheral sex steroids, expression of endometrial estrogen receptors and nitric oxide synthases during the estrous cycle in mares. J Reprod Dev 2011;57: 43-8.

[70] Galvão A, Valente L, Skarzynski DJ, Szóstek A, Piotrowska-Tomala K, Rebordão MR, et al. Effect of cytokines and ovarian steroids on equine endometrial function: an in vitro study. Reprod Fertil Dev 2013:25:985-97. 